\title{
Features of Translation of Terms in Insurance Documentation
}

\author{
Nadezhda A. Goncharova \\ Ural State University of Economics \\ Ekaterinburg, Russia \\ nadin1325x@yandex.ru
}

\author{
Elena A. Shemyakina \\ Ural State University of Economics \\ Ekaterinburg, Russia \\ alerna@bk.ru
}

\begin{abstract}
The gist of this article boils down to the need of integrating Russia into the global space, business development and the exchange of experience with international partners. The object of the study is English-language journalistic texts about the features of life insurance. The subject of the study - insurance terms found in the texts. The purpose of the work is to study insurance-specific terms in English and analyze their translation into Russian. Tasks of work: to define the essence of terms in general and terms in insurance in particular; highlight the features of insurance terminology; to analyze the basic methods of translation of terms; translate texts related to life insurance; identify difficult points in the translation of insurance terms; analyze the origin of terms, word formation; Choose the most suitable Russian equivalent. The hypothesis of the study: the authors consider the advantage of new technologies in translation of terms in insurance documentation at the present stage. Research methods: qualitative and quantitative analysis of the results in translation of terms in insurance documentation at the present stage. The result of the study: the advantage of new technologies in translation of terms in insurance documentation at the present stage. The material of the study was economic terms derived from a typical sample of sources representing the sphere of their functioning, namely, articles related to life insurance.
\end{abstract}

Keywords-insurance; translation of terms; word formation; methods; insurance documentation; method of translation; new technologies; new concepts.

\section{INTRODUCTION}

Insurance - relations for the protection of the interests of individuals and legal entities, the Russian Federation, constituent entities of the Russian Federation and municipal formations upon the occurrence of certain insured events at the expense of monetary funds formed by insurers from paid insurance premiums, as well as at the expense of other insurers' funds.

In developed countries, almost every citizen uses personal insurance, in Russia it has not yet become so popular. However, life and health insurance is really important and beneficial. Unfortunately, at the present stage it is difficult to find universal specialists who speak English and know the insurance industry. Over the past decade, the need to learn foreign languages has more than doubled. This was facilitated by increased demands in the workplace for language skills, a growing flow of tourists abroad, etc. The situation did not change significantly even in times of crisis and Western sanctions: consumers still remain interested in traveling abroad and improving their communication skills with an emphasis on the future [1-14].

\section{ESSENCE, STRUCTURE AND FEATURES OF TERMS TRANSLATION}

Despite the fact that the term is the central object of terminology, there are different points of view on its meaning. The term is a special word (or phrase) accepted in professional activity and used in special conditions; verbal designation of the concept included in the system of concepts of a specific area of professional knowledge; the basic conceptual element of a language for special purposes requires a special definition (precise scientific definition) for its proper understanding. M.N. Volodina defines a term as a word or a word combination of a special sphere of use, created (borrowed, accepted) for the exact expression of special concepts and based on the definition [15]. Z.I. Komarova states that the term is an invariant (word or phrase), which means a special subject or scientific concept, limited to a definition and a place in a certain terminological system [16].

Speaking about the linguistic nature of the term, it is worth noting that, firstly, the term is an integral organic part of the lexical system of a literary language. Secondly, the terms differ from other categories of words by their enormous informational richness. The scientific term gives the most accurate, concentrated and economical definition of a scientific concept. The specificity of terms as a special lexical category of words is that they are created in the process of production and scientific activity and therefore function only among people with relevant scientific and production realities, that is, macro-text. Therefore, in contrast to ordinary words, the uniqueness of which in speech communication is provided by the situation or the linguistic context, the uniqueness of the term is governed by the extra-linguistic macro context or the linguistic micro context.

Depending on the structure of terms, there are:

1. Terms-phrases (for example, a controlled system reguliruyemaya sistema). They are formed by the addition of a term denoting a generic concept, with specific features for obtaining a species concept. Such terms: express holistic concepts, have a different degree of semantic decomposability, 
language, he fills it with equivalent means to create the closest impression possible from two messages.

1. The optimal method of translation is the identification in the language of translation equivalent to the term of the original language. The application of this method is possible in cases where countries in which the original language and the language of the translation are common have reached the same level of social development or have passed this level at some time in their history [17]. This method is actively used in the translation of insurance terms. (ustanovka dlya ochistki "refiner").

2. In some cases, the term should be translated descriptive design. This translation method is used primarily for nonequivalent terms reflecting the realities of a particular country (law of combining volumes).

3. Terms can also be translated using lexical transformations, namely, generalization or specification of values. "Refinement" refers to the replacement of a word or word combination of the original language with a broader meaning with a word or word combination of a translation language with a narrower meaning. The reverse phenomenon, that is, the replacement of the unit of the original language, which has a narrower meaning, the unit of the translation language with a broader meaning, is called "generalization" (potentsial'nyy bar'yer - potential energy barrier (konkretizatsiya); effekt dinamicheskogo vozdeystviya impact effect (generalizatsiya)).

4. The easiest way to transfer is to borrow, which allows you to fill in the gap. Borrowing is the copying (usually incomplete and inaccurate) of a word or expression from one language to another. Borrowing in languages is one of the most important factors for their development (glossary glossariy, slovar').

5. Calque is a borrowing of a special kind: we borrow from a foreign language one or another syntagma and literally translate the elements that make it up. A large number of terms and special vocabulary practically represent calques , i.e. the reproduction is not a sound, but a combinatorial composition of a word or phrase, when the components of a word (morpheme) or phrase (lexeme) are translated by the corresponding elements of the translation language (basic earnings per share bazovyy dokhod na odnu aktsiyu).

6. It is possible to use transliteration and transcription - the exact transfer of characters of one script by signs of another script, or the most accurate transmission of language sounds (okrug - okrug). Transcription occurs when translating proper names and other names (radio - radio).

There are also other techniques for translating terms used by some linguistic scientists, but the data is the most popular and commonly used.

\section{INSURANCE TERMS AS A SPECIAL LANGUAGE LAYER}

Insurance, having appeared in Babylon, became an important type of economic relations, one of the key sectors. based on parallel categories, a direct translation takes place. If the translator is aware of the presence of a "gap" in the 
Naturally, the long-term development of insurance in Englishspeaking countries led to the emergence of a huge number of special terms, professional slang. In Russia, during the period of Soviet power, there was no insurance in the generally accepted sense, and there is no corresponding terminology in Russian. Now everyone who owns a car or goes abroad is facing insurance; translations of insurance documents into Russian or into foreign languages may become necessary.

To correctly understand the text, you need experience in the field of insurance translation, higher special education and constantly monitor changes in terminology, legislation, practice. It is necessary to find verbal turns replacing the generally accepted English term, retaining the official, business style of the document, and for this to know the specifics of insurance, reinsurance, co-insurance, the specifics of the legislation of the country of origin of the text, be prepared to further study its legislation, if necessary for accurate translation. However, sometimes it is necessary to deviate from the literal translation of the text in order to accurately reproduce the semantic content.

The global insurance market is increasing its volume every year, which at the same time requires more serious professional knowledge from legal translators. It should be noted insurance vocabulary, which in the English language very often has no analogues, and only a competent specialist with serious experience in this field can find the equivalent for each term. This is due not only to differences between languages, but also to differences between state legal systems. A good translator relies not only on specialized dictionaries and encyclopedias, but tries to make more active use of insurance vocabulary from various sources, written in the source language. Thus, it is possible to choose the most correct equivalent from among those listed in the dictionary, avoid errors and keep the style of the original.

For example, a simple, at first glance, word like "insurability" can be translated either "strakhovyye sposobnosti", or "strakhovyye vozmozhnosti". It is obvious that a specialist translator will choose the last of the proposed options as the most appropriate term in the insurance environment. Consequently, a professional needs to be proficient not only in a foreign language to understand the essence, but also the specific vocabulary of insurers for correctly formulated transmission of content.

An example of the ambiguity of the term and the difficulty of finding the desired value is the term"carrier". The word is found in sentences "With "participating" whole life policies, the life insurance carrier invests your premiums and you share in the return by receiving dividends", "This insurance coverage may be offered through a variety of carriers" and others. In the dictionary we find the translation options for this word: nosil'shchik, konteyner, bagazhnik, transportnaya kontora [18].

A similar translation in the authentic explanatory dictionary [19]:

1) person or thing that carries, holds, or conveys something;
2) person or company that undertakes the professional conveyance of goods or people;

3) person or animal that transmits a disease-causing organism to others, especially without suffering from it themselves;

4) substance used to support or convey another substance such as a pigment, catalyst, or radioactive material.

Only two dictionaries give, in addition to the listed interpretations, the meaning used in the articles is: an organization acting as an insure; company that underwrites and issues an insurance policy, or is responsible for the administration of a range of insurance policies. In this way, "carrier" - eto strakhovaya kompaniya [20].

The phenomenon of untranslatability in the field of translation of insurance documents is highlighted. Sometimes in the process of translating from English to Russian it is impossible to find the Russian equivalent of the English concept. This terminological problem may arise due to the absence in the Russian language of a concept equivalent to the concept in English. This is called a conceptual space. For example, for foreign insurance, the classification of insurance agents for "tied agents" и "multi-tied agents", that is, agents working exclusively for one insurer, and those who have contracts with several insurance companies. There are no similar terms in the Russian language, therefore the descriptive translation and comments of the translator can serve as a way out of the situation of seeming lack of correspondence to a specific term of the desired equivalent.

Due to the greater development of insurance outside Russia, many insurance terms are borrowed from foreign languages. Consider the proposal "Carrier underwriting policies for smokers vary from company to company, and they change periodically " - Anderrayting polisov dlya kuryashchikh otlichayetsya $\mathrm{v}$ raznykh kompaniyakh i periodicheski menyayetsya. "Underwriting" translate as "anderrayting", what is the process of analyzing the risks offered for insurance. In modern insurance language, underwriters are a necessary position in a company, and underwriting is an essential process for concluding a contract.

Similarly, the term is used. "grace period" - srok otsrochki platezhey, l'gotnyy period."Typically, you will have a 30- or 31-day”. - Obychno vam polagayetsya 30- ili 31-dnevnyy greys-period. In many agreements, it is the duration of the grace period that is prescribed, rather than the grace period.

Calques in the translation of terms is a very common phenomenon. Let's consider an example. "Can I buy a policy on someone else? Yes, but only if you have an "insurable interest" in that person" - "Mogu li ya kupit' polis dlya drugogo cheloveka? Da, no tol'ko yesli u vas yest' strakhovoy interes v strakhovanii etogo cheloveka. So "insurableinterest"is an insurance interest. The translation of the same sentence is an example of the use of literal translation, when no meaning transformation is needed to convey meaning.

In life insurance, you need to understand the terms "insurance amount", "insurance coverage", "insurance compensation". For this we use the most optimal method of 
translation - the search for equivalents in the Russian language.

We meet in one sentence at once three terms: "Cash value is the total of premiums paid plus interest and applied dividends, minus fees and expenses including the surrender charge. It is held by the carrier to cover the death benefit and as collateral for any loans you take. Once the cash value reaches the policy's stated death benefit (i.e., face value of the policy), you can continue to put the dividends into your policy to add to the cash value to increase the death benefit."

Cash Value - a particular form of life insurance whereby the premium typically remains level throughout the life of the policy and a portion of that premium goes towards the death benefit while another portion of the premium goes towards a cash account that earns interest for the policy holder. Это сумма накоплений по полису, она образуется за счет части страховой премии, направляемой в инвестиционный фонд.

Death benefit - face-amount of a life insurance policy payable to its beneficiary on the death of the insured. Verbatim, this is insurance benefit payable at death for the insured person. In the Russian practice, this is the Insurance coverage - insurance payments made upon the occurrence of the insured event to the Insured, Beneficial for the acquirer or heir of the Insured under the law. The payment is the sum of the nominal amount of the insurance contract, plus the amount due on the additions, minus the loans paid and interest on them.

Face value $=$ Face amount - Sum of money for which an insurance cover is obtained, usually shown on the top sheet (face) of the policy. In life insurance, face amount is the sum paid on the policy's maturity date, on the death of the insured, or (if the policy terms permit) on his or her total disability. Insurance amount - a sum of money determined by the insurance contract, established for each insured event separately, on the basis of which the size of the insurance premium (insurance premium) and insurance coverage are determined. This is the nominal amount (without any recalculations and indexations), the insurance amount provided under the terms of the insurance policy, which, as a rule, is given on the first page or in the application part of the policy.

Another term about the amount found in life insurance is "surrender value" or "cash surrender". "Surrender value is determined by taking the amount of cash in the policy, minus the surrender charge".

Cash surrender value (CSV) - Amount the holder of a life insurance policy (that has cash value) is entitled to receive, on its surrender (cancellation) before the death of the insured or before the policy matures. This sum is based on the insurance premium paid up to the surrender date less surrender fee. Also called cash value or surrender value, it may be used as collateral for borrowing from the insurance company or a bank. In other words, this is the amount paid in case of waiver of rights under the policy, i.e. money that the policy holder has the right to receive from the insurance company after the waiver of rights under the life insurance policy before the due date for payment of the policy or specified in the insurance event. The amount represents the cash value minus the costs associated with the waiver of rights under the policy, as well as any outstanding loans and interest associated with them. The equivalent term in the Russian language is the redemption amount - the amount stipulated by the insurance contract that is paid to the policyholder upon early termination or termination of the insurance contract.

Also there are terms- phrases. . "A whole life policy is an endowment policy and is structured to endow (have the cash value equal the face amount) usually at age 100." In the phrase used the word "endowment" which means "pozhertvovaniye, dar, vklad". In the insurance industry "endowment policy" This is a combination of insurance and investment plans, i.e. insurance-contribution, insurance for survival up to a certain age.

Another variant of the policy - "participating policy". "You would have to have a participating policy and put the dividends into the cash value to surpass the face amount at an earlier age." From the words used it follows that the policy implies some kind of participation, but in order to fully and accurately explain the term we have to resort to specification, and translate the term as "insurance policy with profit-sharing of the insurance company".

The general methods of translation used when working with terms in different scientific fields are also applicable in the field of insurance. The possibility of a wide choice of translation methods allows the translator to choose the most equivalent option.

\section{CONCLUSION}

One of the most difficult tasks is the translation of insurance documents. The complexity of the translation of insurance documents lies in the lexical features of a foreign language. The emergence of new lexical constructions and terms requires a translator, both an excellent knowledge of the language and specific disciplines.

In the course of this work, the tasks set by the author were solved. In particular, the essence of terms, including insurance, are defined, and the methods of translation of terms are analyzed and their practical application is shown when working with insurance texts.

When translating insurance terms, as well as when translating other scientific concepts, generally accepted methods of translating terms are used. The most optimal is the search for an equivalent term in the translated language. Borrowing or tracing, which are used when new concepts are introduced into the target language, is also very popular. In the absence of an equivalent in the language of translation, a descriptive translation is also used, which is an explanation of the term being translated.

In connection with the relevance of the topic being studied, the achievement of the goal of the work - the study of specific insurance terms and methods of their translation - has significant practical and practical significance for further work in the insurance and foreign languages. 
pseudo-relevant documents, Information Processing \& Management, Vol. 53, Issue 2, pp 371-387, 2017.

To carry out a high-quality translation of insurance texts, it is necessary not only to thoroughly understand the methods of translating terms, but also to learn professional vocabulary, both in the source language and in the target language.

\section{References}

[1] Yangqiu Song, Shyam Upadhyay, Haoruo Peng, Stephen Mayhew, Dan Roth, Toward any-language zero-shot topic classification of textual documents, Artificial Intelligence, Volume 274, pp 133-150, 2019.

[2] Javid Dadashkarimi, Azadeh Shakery, Heshaam Faili, Hamed Zamani, An expectation-maximization algorithm for query translation based on pseudo-relevant documents, Information Processing \& Management, Vol. 53, Issue 2, pp 371-387, 2017.

[3] Sally L. Baxter, Helena E. Gali, Abigail E. Huang, Marlene Millen, Lucila Ohno-Machado, Time Requirements of Paper-Based Clinical Workflows and After-Hours Documentation in a Multispecialty, American Journal of Ophthalmology, Vol. 206, pp 161-167, 2019.

[4] Elisa Alonso, Google and Wikipedia in the Professional Translation Process: A Qualitative Work, Social and Behavioral Sciences, Vol. 173, pp 312-317, 2015.

[5] Daniel J. Vreeman, Maria Teresa Chiaravalloti, John Hook, Clement J. McDonald, Enabling international adoption of LOINC through translation, Journal of Biomedical Informatics, Vol. 45, Issue 4, pp 667673, 2012.

[6] Debajyoty Banik, Asif Ekbal, Pushpak Bhattacharyya, Siddhartha Bhattacharyya, Assembling translations from multi-engine machine translationoutputs, Applied Soft Computing, Vol. 78, pp 230-239, 2019.

[7] Valentina Shiryaeva, Georgiana Lungu Badea, The Role of Context in Defining Romanian Equivalents for Russian Terms in the Theory of Translation, Social and Behavioral Sciences, Vol. 92, pp 874-879, 2013.

[8] Javid Dadashkarimi, Azadeh Shakery, Heshaam Faili, Hamed Zamani, An expectation-maximization algorithm for query translationbased on
[9] Anna Claudia Ticca, Véronique Traverso, Participation in bilingual interactions: Translating, interpreting and mediating documents in a French social centre, Journal of Pragmatics, Vol. 107, pp 129-146, 2017.

[10] Linda R. Watson, Translation and cultural adaptation of parent-report developmental assessments: Improving rigor in methodology, Research in Autism Spectrum Disorders, Vol. 62, pp 55-65, 2019.

[11] Shemyakina Ye. A., Trudnosti perevoda reklamnykh tekstov, Problemy inzhenernogo i sotsial'no-ekonomicheskogo obrazovaniya v tekhnicheskom vuze v usloviyakh modernizatsii vysshego obrazovaniya, S. 378-381, 2018 .

[12] Goncharova N. A., Transformatsii frazeologicheskikh yedinits v yazyke pressy, Nauchno-metodicheskiy elektronnyy zhurnal kontsept, T. 31, S. 746-750, 2017.

[13] Shemyakina Ye. A., Osobennosti perevoda reklamy na russkiy yazyk, Glavnyye voprosy sovremennoy nauki, S. 144-147. 2017.

[14] Goncharova N. A. Rol' delovogo pis'ma na sovremennom etape, Problemy inzhenernogo i sotsial'no-ekonomicheskogo obrazovaniya v tekhnicheskom vuze $\mathrm{v}$ usloviyakh modernizatsii vysshego obrazovaniya, S. 208-211, 2018.

[15] Volodina M.N. Teoriya terminologicheskoy nominatsii [Tekst]. M., 1997 , s. 25

[16] Komarova Z.I. Semanticheskaya struktura spetsial'nogo slova i yeyeleksikograficheskoye opisaniye [Tekst]. Sverdlovsk, 1991.

[17] Tsentr pomoshchi nauchnym issledovaniyam "Sciencefiles" [Elektronnyy resurs]. - Rezhim dostupa: http://www.sciencefiles.ru/

[18] Business dictionary [Electronic resource], Access Mode: http://www.businessdictionary.com/

[19] Merriam-Webster Online Dictionary [Electronic resource], Access Mode: http://www.merriam-webster.com/

[20] Oxford dictionaries [Electronic resource], Access Mode: http://oxforddictionaries.com/ 